\title{
Akurasi Arah Kiblat Masjid dengan Metode Mizwala Qibla Finder di Kecamatan Pademawu Kabupaten Pamekasan
}

\author{
Hosen \\ (Jurusan Syariah IAIN Madura, Jln Raya Panglegur, Km. 4 Pamekasan, email: \\ hasta78@ymail.com) \\ Ghafiruddin \\ (Jurusan Syariah IAIN Madura, Jln Raya Panglegur, Km. 04 Pamekasan, email: \\ ghafiruddin86@gmail.com)
}

\begin{abstract}
Abstrak:
Persoalan menghadap kiblat yang merupakan salah satu rukun shalat menjadi perhatian khusus, terutama orang-orang yang tinggal jauh dari kota Mekkah. Dalam artikel ini ada tiga hal pokok yang menjadi pembahasan. Pertama, alat apa yang digunakan untuk mengukur arah kiblat masjid diwilayah Kecamatan Pademawu Kabupaten Pamekasan. Kedua, bagaimana proses pengukuran dan penetapan arah kiblat masjid diwilayah Kecamatan Pademawu Kabupaten Pamekasan. Dan ketiga, bagaimana hasil akurasi arah kiblat masjid di wilayah Kecamatan Pademawu Kabupaten Pamekasan menurut metode Mizwala Qibla Finder (MQF). Penelitian ini berlokasi di sejumlah masjid di wilayah Kecamatan Pademawu Kabupaten Pamekasan. Metode yang digunakan adalah pendekatan kualitatif (qualitative approach) dalam bentuk analisis deskriptif. Data-data dalam penelitian ini diperoleh melalui wawancara, observasi, catatan lapangan dan dokumentasi. Analisis data pada penelitian ini dilakukan melalui tahapan reduksi data, penyajian data dan penarikan kesimpulan. Hasil penelitian ini menunjukkan; (1) terdapat beberapa alat pengukur arah kiblat yang digunakan di beberapa masjid, seperti Rubu' Mujayyab, kompas dan bhencèt/tongkat istiwâ', meteran dan benang. (2) proses pengukuran arah kiblat masjid di lakukan dengan cara melibatkan beberapa elemen masyarakat mulai dari tokoh, aparat desa dan masyarakat yang ada di wilayah tersebut. (3) akurasi arah kiblat masjid di wilayah Kecamatan Pademawu Kabupaten Pamekasan dengan menggunakan metode/alat Mizwala hanya $28,57 \%$ (6 masjid) dari jumlah sampel yang arah kiblatnya akurat. Tulisan ini diharapkan menjadi acuan untuk melakukan
\end{abstract}


penelurusan lebih lanjut terhadap arah kiblat masjid di daerah lainnya.

\title{
Kata Kunci:
}

Akurasi, Arah Kiblat Masjid, Mizwala Qibla Finder, Ka'bah

\begin{abstract}
:
The problem of facing up the qibla as one of prayer's pillars takes much attention mainly from those who live far away from Mecca. This article particularly discusses three topics. First, what kind of instrument used to measure the mosque qibla in the area of Pademawu Sub-district, Pamekasan. Second, how does the process of measurement and establishment of qibla in Pademawu take place. Third, how is the result of mosque qibla accuracy in Pademawu Subdistrict according to Mizwala Qibla Finder (MQF). Meanwhile, this research focuses on some mosques in Pademawu Sub-district using the method of qualitative approach in analytical descriptive ones. The data of this research is obtained from interview, observation, field note, and documentation. Later on, the analysis data process is through the step of data reduction, data delivery and conclusion making. The result of this research shows these following points; (1) there found some measurement instruments of qibla direction in the mosques, such as Rubu' Mujayyab, compass and istiwa' stick, meter indicator and sewing. (2) The process of mosque qibla measurement involves some elements in the society ranging from key figures, village apparatus to local people. (3) The accuracy of qibla direction in Pademawu Sub-district using Mizwala method/instrument is only $28.57 \%$ or 6 mosques of all samples with the accurate direction. Hopefully, this writing becomes guidelines to do more research on qibla direction in other mosques
\end{abstract}

\section{Keywords:}

Acuracy, Mosque Qibla Direction, Mizwala Qibla Finder, Ka'bah

\section{Pendahuluan}

Menghadap kiblat (Baitullah) dalam agama Islam merupakan salah satu syarat sahnya shalat seseorang. Bagi orang-orang yang tinggal di daerah kota Mekkah, persoalan menghadap kiblat tentulah tidak sulit. Karena mereka bisa menyaksikan secara langsung posisi Ka'bah. Namun beda halnya dengan umat Islam yang tinggal jauh dari kota Mekah serta tidak mampu melihat ke arah Ka'bah secara 
langsung. Untuk itu, bagi mereka yang tinggal jauh dari kota Mekkah wajib berijtihad untuk mendapatkan arah kiblat yang akurat.

Alqur`an menyebut kata al-qiblah sebanyak 6 kali yang kesemuanya terdapat dalam surat al-Baqarah yang diartikan sebagai "Ka'bah"1, "Arah ke Ka'bah di Mekkah (pada waktu shalat)"2, atau "Arah yang dituju kaum muslimin dalam melaksanakan sebagian ibadah"3. Dasar hukum kewajiban menghadap kiblat termaktub dalam Q.S al-Baqarah (2) :144, 149 dan 1504. Didukung oleh beberapa hadits Rasul yang diriwayatkan oleh para perawi terkenal. ${ }^{5}$ Titik tekan arah yang dimaksud dalam kiblat adalah syathr ${ }^{6}$ yang merupakan garis yang menghimpit antara posisi Ka'bah dengan posisi seseorang di muka bumi. Di era klasik, menentukan arah kiblat cukup dengan menggunakan petunjuk atlas atau kompas tertentu.

Seiring berkembangnya ilmu pengetahuan dan teknologi terdapat banyak cara atau metode yang bisa digunakan dalam menentukan arah kiblat. Mulai dari sistem klasik sampai sistem

1 Ahmad Warson Munawwir, Kamus al-Munawwir; Arab-Indonesia, (Yogyakarta: Pustaka Progresif, 1984), 1169.

2 Abdul Azis Dahlan, et. Al., Ensiklopedi Hukum Islam, Jilid 3 (Jakarta: Ichtiar Baru van Hoeve, 1996), 944.

${ }^{3}$ Majd al-Dîn Muhammad bin Ya'qûb al-Fairuz Abadî al-Syirâzî, al-Qâmûs al-Muhîth, juz 2, (Kairo: al-Hay`ah al-Mishriyyah, t.t.), 57.

4 QS. 2:144

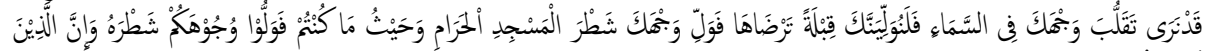

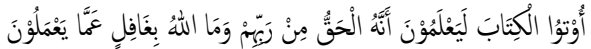

QS. 2:149

QS. 2:150

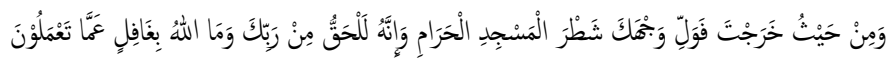

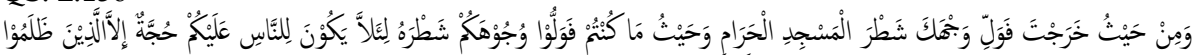

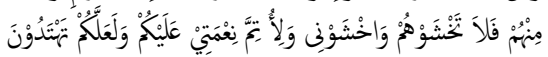

${ }^{5}$ Hadits riwayat Imâm Bukhârî dari Ibn 'Abbâs dalam kitab Fath al-Bârî bi Syarh Shahîh al-Imâm Abî 'Abd Allâh Muhammad bin Ismâil al-Bukhârî, tahqîq 'Abd alQâdir Syaibah al-Hamd, Juz IV (Riyâdl: al-Amir Sulthân bin 'Abd al-Azîz Âlu Saud, 2001), 597, hadits nomor 394.

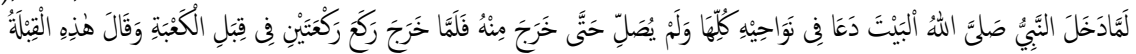

Ada pula hadits riwayat Baihaqî dari Abu Hurairah dalam kitab al-Sunan al-Kubrâ, Tahqîq 'Abd Qâdir Athâ, juz 2 (Beirut: Dâr al-Kutub al-Ilmiyyah, 2003), 16.

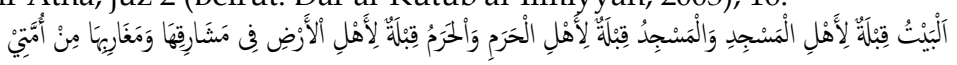

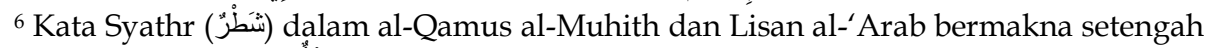

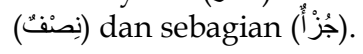


kontemporer. Diantara sistem klasik yang digunakan adalah kompas7, Rasyd al-Qiblah ${ }^{8}$, Rub al-Mujayyab ${ }^{9}$ dan al-Durûs al-Falakiyyah ${ }^{10}$ jilid ke1 yang di dasarkan pada perhitungan segi tiga bola dan mengacu pada titik $90^{\circ 11}$ dan jilid ke-2 yang sudah menggunakan perhitungan trigonometri (sinus dan cosinus) yang ada dalam sistem kalkulator. ${ }^{12}$ Ada juga metode lain seperti kitab Irsyâd al-Murîd ${ }^{13}$ yang

\footnotetext{
7 Kompas atau magnetic compass, ada juga yang menyebutnya huk atau ibrah almaghnithisiyyah adalah alat yang digunakan untuk mengetahuai arah. Di dalamnya terdapat jarum yang bermagnet yang senantiasa menunjukkan arah utara dan selatan. Hanya saja arah utara yang ditunjukkan olehnya bukanlah arah utara sejati (titik kutub utara bumi), sehingga untuk mendapatkan arah utara sejati (true north) perlu adanya koreksi deklinasi kompas terhadap arah jarum kompas. Deklinasi kompas ini selalu berubah-ubah tergantung pada posisi tempat dan waktu. Lihat Muhyiddin Khazin, Kamus Ilmu Falak, (Jogjakarta: Buana Pustaka, 2005), 31. Selanjutnya disebut Khazin.

8Ketentuan waktu dimana bayangan benda yang terkena sinar matahari menunjuk ke arah kiblat. Dalam Kalender Menara Kudus yang disusun oleh KH. Turaihan Ajhuri ditetapkan bahwa setiap tanggal 28 Mei dan tanggal 15/16 Juli dinamakan Yaum alRasyd al-Qiblah karena pada tanggal-tanggal tersebut dan jam yang ditentukan matahari tepat berada di atas Ka'bah. Lihat Susiknan Azhari, Ensiklopedi Hisab Rukyat, (Yogyakarta: Pustaka Pelajar, 2012), 179. Selanjutnya disebut Azhari.

${ }^{9}$ Dalam isitlah astronomi disebut kuadran, yaitu suatu alat untuk menghitung fungsi trigonometri yang sangat berguna untuk memproyeksikan peredaran benda langit pada lingkaran vertikal. Bagian-bagian dari Rubu' terdiri: (1) Qaus (busur); bagian yang melengkung, (2) Jaib (Sinus); satu sisi tempat mengincar, yang memuat skala yang mudah terbaca berapa sinus dari tinggi suatu benda langit yang dilihat, (3) Jaib al-Tamam (Cosinus); yang memuat skala-skala yang mudah terbaca berapa cosinus dari tinggi benda tesebut, (4) Awwal al-Qaus (permulaan busur); bagian busur yang berimpit dengan sisi jaib al-tamam, (5) Akhir al-Qaus; bagian busur yang berimpit dengan sisi jaib. Dari awal qaus sampai akhir qaus dibagi-bagi dengan skala dari 0 derajat sampai dengan 90 derajat, (6) Hadafah (sasaran); lubang untuk mengincar, (7) Markaz; titik sudut siku-siku, pada sudut ini terdapat lubang kecil untuk dimasuki tali yang biasanya dari sutera, maksudnya supaya tali itu dibuat sekecil-kecilnya, (8) Mûri; simpulan benang kecilyang dapat digeser, dan (9) Syaqûl; ujung tali yang diberi beban yang terbuat dari metal. Lihat Ibid., 181-182.

10Sebuah kitab klasik yang membahas tentang ilmu falak yang dikarang oleh Syaikh Muhammad Ma'shûm bin Alî Jombang.

11 Syaikh Muhammad Ma'shûm bin Alî, al-Durus al-Falakiyyah, Jilid I (Jombang: TP, 1992), 13.

12 Ibid. 50-51.

13Irsyâd al-Murîd ilâ Ma'rifah 'Ilm al-Falak alâ al-Rasyd al-Jadîd, kitab yang membahas ilmu falak yang dikarang oleh KH. Ahmad Ghazâlî Muhammad Fathullâh, Pengasuh Pondok Pesantren Al-Mubarak, Lanbulan Sampang.
} 
menggunakan istilah azimuth ${ }^{14}$ dan mengacu pada titik $0^{\circ}-360^{\circ}$ searah jarum jam yang perhitungannya menggunakan kalkulator. ${ }^{15}$

Selain metode klasik sebagaimana disinggung diatas, terdapat pula metode-metode yang berbasis kontemporer. Seperti metode Ephemiris Hisab Rukyat16, Mizwala Qibla Finder (MQF)17, Istiwâ'ain ${ }^{18}$ dan Teodolite ${ }^{19}$ yang merupakan kolaborasi antara hasil hisab (hitungan) dengan posisi dan bayangan sinar matahari pada suatu waktu. ${ }^{20}$ Dengan banyaknya metode pengukuran arah kiblat yang terus berkembang, penggunaan metode yang paling akurat menjadi salah satu hal penting yang perlu diperhatikan saat hendak melakukan pengukuran/pengecekan arah kiblat. Sebab setiap metode pastilah memiliki kekurangan dan kelebihan masing-masing.

\footnotetext{
${ }^{14}$ Azimut adalah harga suatu sudut untuk tempat atau benda langit yang dihitung sepanjang horizon (ufuk) dari titik utara ke timur searah jarum jam sampai titik perpotongan antara lingkaran vertikal yang melewati temapt atau benda langit itu dengan lingkaran horizon. Lihat Muhyiddin Khazin, Kamus..., 40.

15 Ahmad Ghazâlî Muhammad Fathullâh, Irsyâd al-Murîd (Sampang: cetakan ke 3, Lajnah Falakiyah al-Mubarok Lanbulan, 2005), 13-15.

16Sebuah buku yang terbit setiap tahun dan diterbitkan oleh Departemen Agama RI (sekarang Kementerian Agama) yang berisi tabel astronomis (data matahari dan bulan) selama satu tahun. Selain itu juta dimuat data ijtimak, tinggi hilal, gerhana, dan contoh perhitungan arah kiblat, awal waktu shalat dan awal bulan kamariah. Lihat Azhari, Ensiklopedi..., 62.

17Mizwala Qibla Finder (MQF) adalah sebuah alat pengecek atau pengukur azimut syathr kiblat yang merupakan modifikasi dari tongkat istiwa` (sundial) yang terdiri dari beberapa komponen seperti gnomon (tongkat pembentuk bayangan), bidang level dan bidang dial putar. Lihat Hosen, Zenit; Panduan Perhitungan Azimut Syathr Kiblat dan Awal Waktu Shalat, (Pamekasan: Duta Media, 2016), 142.

18Istiwâ'ain adalah salah satu alat penentu/pengukur arah kiblat yang diciptakan oleh KH. Slamet Hambali, salah satu tokoh ilmu falak Indonesia. Alat ini dilengkapi oleh dua tongkat istiwâ' (gnomon) untuk menandai bayangan sinar matahari pada suatu waktu. Untuk penentuan bayangan mataharinya, alat ini juga dilengkapi dengan software yang dibuat khusus untuk memudahkan penghitungan.

${ }^{19}$ Teodolite adalah alat yang digunakan untuk menentukan tinggi dan azimut suatu benda langit. Alat ini mempunyai dua sumbu, yaitu sumbu "vertikal" untuk melihat skala ketinggilan benda langit, dan sumbu "horizontal" untuk melihat skala azimutnya, sehingga teropong (lub) yang digunakan untuk mengincar benda langit dapat bebas bergerak ke semua arah. Lihat Azhari, Ensiklopedi..., 216.

${ }_{20}$ Hendro Setyanto, Mizwala Qibla Finder, makalah disampaikan dalam pelatihan hisab dan rukyat, Lajnah Falakiyah Nahdhatul Ulama (LFNU), (Pamekasan, 12 Mei 2010). Selanjutnya disebut Hendro.
} 
Dalam penelitian ini penulis memilih menggunakan Mizwala Qibla Finder (MQF) (selanjutnya disebut Mizwala) sebagai alat pengukuran/penentuan arah kiblat. Karena Mizwala merupakan salah satu alat/metode pengukuran arah kiblat yang modern dan cukup akurat. Penelitian ini berlokasi di sejumlah masjid di wilayah Kecamatan Pademawu Kabupaten Pamekasan. Lokasi ini merupakan salah satu kecamatan terluas di Kabupaten Pamekasan. Terdiri dari 22 desa dengan jumlah masjid sekitar 99 buah se-Kecamatan Pademawu. Sebagian besar masjid yang menjadi sampel sudah lama di bangun. Dan ada beberapa masjid yang sudah direnovasi. Terhadap masjid yang direnovasi tersebut tidak dilakukan pengecekan kembali arah kiblatnya karena mengikuti arah kiblat bangunan yang sudah ada. Asumsi penulis, tidak dilakukannya pengecekan kembali arah kiblat dikarenakan pihak takmir tidak mengetahui tata-cara mengukur arah kiblat.

Tulisan ini akan membahas: alat apa yang digunakan untuk mengukur arah kiblat masjid di wilayah Kecamatan Pademawu kabupaten Pamekasan, bagaimana proses pengukuran dan penetapan arah kiblat masjid diwilayah Kecamatan Pademawu Kabupaten Pamekasan, dan bagaimana akurasi arah kiblat masjid di wilayah Kecamatan Pademawu kabupaten Pamekasan menurut metode Mizwala Qibla Finder (MQF).

Untuk menjawab permasalahan tersebut diatas, penulis melakukan serangkaian wawancara dengan takmir masjid yang menjadi sampel dalam penelitian ini. Wawancara tersebut dimaksudkan untuk memperoleh informasi dan data tentang alat yang digunakan ketika mengukur/menentukan arah kiblat masjid setempat. Selain itu juga, wawancara berikutnya untuk mengetahui proses pengukuran atau penentuan arah kiblat masjid sesuai dengan alat yang digunakan. Langkah selanjutnya, penulis menggunakan Mizwala untuk mengetahui keakurasian arah kiblat masjid yang menjadi sampel sebagai bahan perbandingan atas arah kiblat yang telah ditentukan sebelumnya.

Komponen-komponen dalam Mizwala antara lain: (1) bidang level; yaitu bidang yang berfungsi sebagai alas bidang dial dan pengatur kedataran (level). ${ }^{21} \mathrm{Di}$ samping itu, bidang level juga di

${ }^{21}$ Hendro, Mizwala, makalah. 
lengkapi dengan kompas sebagai panduan arah mata angin oleh jarum yang ada padanya. (2) Bidang Dial Putar; adalah alat yang berfungsi sebagai bidang untuk membentuk bayangan yang digunakan sebagai acuan pengukuran. Bidang ini dilengkapi dengan "lingkaran-lingkaran kosentris sebagaimana tongkat istiwa pada umumnya. Serta skala busur dengan skala terkecil 15 menit busur yang emungkinkan untuk memperoleh ketelitian yang mencukupi untuk menentukan arah kiblat." ${ }^{22}$ Dan (3) Gnomon ${ }^{23}$; merupakan komponen utama dalam sundial/tongkat istiwa' yang berfungsi sebagai pembentuk bayangan. Ukuran Gnomon disesuaikan dengan lingkaran diameter bidang dial mizwala. ${ }^{24}$

Untuk kesempurnaan dan lebih akurasinya hasil pengukuran/pengecekan dengan mizwala ini, dibutuhkan alat-alat lain sebagai penunjang, seperti; (1) global positioning system (GPS) ${ }^{25}$ yang berfungsi untuk menentukan posisi tempat (koordinat geografis/lintang dan bujur tempat) di lokasi observasi, dan (2) waterpass $^{26}$ yang berfungsi untuk penyeimbang kedataran bidang (level).

${ }^{22}$ Ibid.

23 Gnomon atau lebih dikenal dengan tongkat istiwa' adalah tongkat biasa yang ditancapkan tegak lurus pada bidang datar ditempat terbuka (sinar matahari tidak terhalang). Kegunaannya untuk menentukan arah secara tepat dengan menghubungkan dua titik (jarak kedua titik ke tongkat harus sama) ujung bayangan tongkat saat matahari di sebelah timur dengan ujung bayangan setelah matahari bergeser ke barat. Kegunaan lain adalah untuk mengetahui posisi dan ketinggian matahari. Lihat Azhari, Ensiklopedi..., 105.

24 Hendro, Mizwala.

25 Global positioning system (GPS) adalah sistem untuk menentukan letak di permukaan bumi dengan bantuan penuylarasan (synchronization) sinyal satelit. Sistem ini menggunakan 24 satelit yang mengirimkan sinyal gelombang mikro (gelombang elektromagnetik dengan frekuensi super tinggi diatas $3 \mathrm{GHz}$ ) ke bui. Sinyal ini diterima oleh alat penerima di permukaan dan digunakan untuk menentukan letak, kecepatan, arah dan waktu. Lihat https://id.wikipedia.org/wiki/Sistem_Pemosisi_Global, diakses pada tanggal 1 Agustus 2018, pukul 08.58.

26 Waterpass adalah alat yang digunakan untuk mengukur atau menentukan sebuah benda atau garis dalam posisi rata baik pengukuran secara vertikal maupun horizontal. Terdapat dua buah alat pengecek kedataran baik untuk vertikal maupun horizontal yang terbuat dari kaca yang didalamnya terdapat gelembung cairan dan pada posisi pinggir alat terdapat garisan pembagi yang dapat dipergunakan sebagai 
Cara menggunakan Mizwala dalam menentukan arah kiblat:27 pertama; menyiapkan Mizwala ditempat yang datar dengan menggunakan bantuan waterpass pada bidang dialnya. Kedua; mencocokkan jam yang digunakan dengan GPS atau melalui website jam.bmkg.go.id atau time.is untuk ketepatan waktu. Ketiga; mencari titik koordinat lokasi yang akan diukur azimut syathr (arah) kiblatnya dengan menggunakan GPS atau Google Earth untuk titik koordinat yang lebih akurat. Keempat; memasukkan data koordinat lokasi, berupa nilai lintang dan nilai bujur ke dalam program mqf.xls (software ini memang dibuat sebegai pelengkap pemakaian Mizwala). Kelima; memperhatikan bayangan tongkat istiwa` (gnomon). Kemudian mencatat waktunya dan meluruskan benang dengan bayangan. Keenam; memutar bidang dial hingga angka mizwah (dalam program Excel) sejajar dengan benang sesuai jamnya. Ketujuh; memindahkan benang pada nilai Qiblat (dalam program Excel) yang sudah tertera. Dan kedelapan; memberi tanda/garis lurus pada benang yang menunjukkan arah kiblat.

\section{Metode Penelitian}

Penelitian ini menggunakan pendekatan kualitatif (qualitative approach), dengan meneliti pemahaman masyarakat di wilayah Kecamatan Pademawu dalam mengukur dan menentukan arah kiblat masjidnya. Populasi dan sampelnya adalah masjid-masjid jamik yang ada di wilayah Kecamatan Pademawu Kabupaten Pamekasan. Dari 99 buah masjid jamik yang tersebar di 22 desa di Kecamatan Pademawu Kabupaten Pamekasan, penulis mengambil sampel sebanyak 21 masjid sebagai obyek penelitian. Jenis sampling yang diambil dalam penelitian ini adalah sampel bertujuan dan pertimbangan atau purposive sampling. Teknik pengumpulan data yang digunakan dalam penelitian ini adalah wawancara (interview) terstruktur, observasi (pengamatan) non partisipan, dan analisis dokumen.

Wawancara dilakukan bertujuan untuk memperoleh informasi terkait peralatan apa saja yang digunakan masyarakat di Kecamatan Pademawu ketika melakukan pengukuran arah kiblat dan informasi

alat ukur penjang. Lihat https://id.wikipedia.org/wiki/Waterpass, diakses pada tanggal 1 Agustus 2018, pukul 09:01.

27 Hosen, Zenit..., 143-147. 
tentang bagaimana cara mengukur arah kiblat dengan menggunakan alat yang berbeda-beda pada beberapa masjid. Sementara observasi dilakukan untuk mengecek secara langsung arah kiblat masjid yang dijadikan sampel dengan menggunakan Mizwala.

Analisis data dalam penelitian ini dilakukan setelah seperangkat fakta atau informasi diperoleh, baik melalui wawancara, observasi maupun dokumentasi. Data-data tersebut kemudian ditelaah dan dianalisis sesuai klasifikasinya untuk kemudian dilakukan reduksi data untuk mencapai kesimpulan.

\section{Kewajiban Menghadap Kiblat}

Pada dasarnya kiblat diambil dari bahasa Arab yang berarti hadapan ${ }^{28}$ yang menunjuk ke suatu tempat. Saat melaksanakan ibadah shalat lima waktu umat Islam diwajibkan menghadap kiblat. Sebab menghadap kiblat merupakan salah satu syarat sahnya shalat. Dalam literatur lain dijelaskan bahwa "kiblat (Arab: qiblah) berasal dari kata "muqâbalah" yang artinya "berhadapan" (muwajahah). Asal mulanya ialah situasi yang ada pada orang yang datang menghadap. Lalu diartikan secara khusus untuk "arah" dimana setiap mushalli (orang yang shalat) harus menghadap kepadanya." 29

Dalam definisi lain disebutkan bahwa yang di maksud dengan kiblat adalah mata angin yang menuju ke Ka'bah di Makkah alMukarramah. Kamus Besar Bahasa Indonesia (KBBI) mengartikan kiblat sebagai arah ke Ka'bah di Mekkah (pada waktu shalat), sementara Ensiklopedi Hukum Islam menerjemahkannya sebagai bangunan Ka'bah atau arah yang dituju kaum muslimin dalam melaksanakan sebagian ibadah. ${ }^{30}$

Dari keterangan di atas dapat disimpulkan bahwa arah yang dihadap oleh umat Islam ketika melaksanakan shalat adalah Ka'bah di Masjidil Haram, Mekkah, Arab Saudi. Yaitu tempat suci yan dibangun pertama kali di muka bumi untuk mentauhidkan Allah,

${ }^{28}$ Abid Bisri, Kamus al-Bisri (Surabaya: Pustaka Progressif, 1999), 583.

${ }^{29}$ A. Kadir, Fiqh Qiblat (Yogyakarta: Pustaka Pesantren, 2012), 51. Selanjutnya disebut Kadir.

30 Ibnu Zahid Abdo el-Moeid, Menentukan Arah Qiblat Dengan Benar, Makalah disampaikan dalam diklat ilmu falak Tsamrah al-Fikar \& Arah Qiblat, Ponpes "AlMubarok" Lanbulan Batusarang Tambelangan (Sampang: 1-2 Mei 2011), 1. 
serta menyingkirkan semua bentuk kemusyrikan. ${ }^{31}$ Masjidil Haram sebagaimana termaktub dalam firman Allah pada mulanya hanya berupa rumah biasa, yang kemudian dilakukan perluasan-perluasan dari tahun ke tahun. Di dalam Masjid al-Haram ini terdapat banyak tempat-tempat mulia, mulai dari Ka'bah, maqâm Ibrahim, hingga Zamzam.

Menghadapkan wajah ke arah kiblat, yakni ke arah Ka'bah di Mekkah saat melaksanakan shalat bukanlah hasil imajinasi manusia sendiri, melainkan hal itu merupakan titah langsung dari Allah swt. Perintah menghadap kiblat disebutkan beberapa kali dalam Alqur'ân maupun hadits Nabi Muhammad saw. Selain itu artikulasi Ka'bah sebagai arah kiblat bukan berarti hal itu menjadi suatu bentuk penyucian atau pensakralan terhadap suatu arah tertentu, melainkan hal itu semata-mata merupakan wujud ketaatan terhadap perintah Allah swt sebagaimana telah banyak disebutkan dalam nash Alqur'ân maupun hadits.

Dasar hukum tentang wajibnya menghadap kiblat tidak hanya tertuang dalam al-Qur'ân sebagai sumber hukum yang pertama tetapu juga dalam hadits Rasulullah. Di antara hadits yang berkaitan dengan penjelasan dan dasar menghadap kiblat yaitu hadits yang diriwayatkan oleh Imam Tirmidzî̀

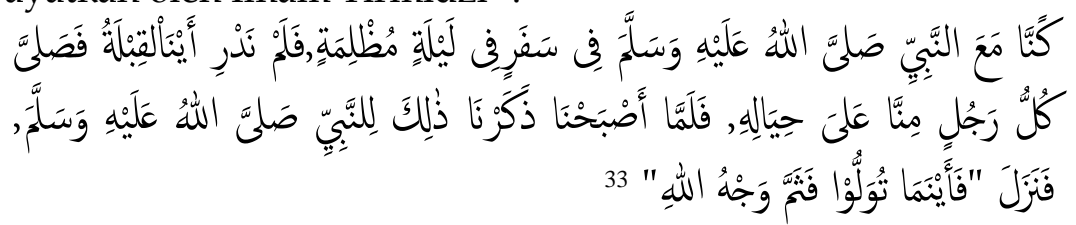

"Pernah kami beserta Nabi saw dalam perjalanan disatu malam yang gelap, kami belum tahun kemana arah kiblat, lalu masing-masing

\footnotetext{
31Kadir, Fiqh..., 52.

32 Nama lengkapnya Muhammad bin 'Îsâ al-Tirmidzî bin Saurah bin Mûsâ al-Sulamî al-Hâfidh, dilahirkan pada tahun 209 Hijriyah. Belajar hadits dari Abû 'Abdullâh alBukhârî. Dilahirkan di kampung Bugh pinggiran sungai Balkh sebuah daerah yang berjarak 6 farsakh dari kota Tirmidz. Wafat di kota Tirmidz pada tanggal 13 Rajab 279 $\mathrm{H}$ dalam usia 79 tahun. Lihat al-Dzahabî, Mukhtârât min Siyari A'lâm al-Nubalâ'wa Târîkh al-Islâmî (Yordania: Dâr al-Nafâis, 2015), 11-13.

${ }^{33}$ Abû Îsâ Muhammad bin Îsâ bin Saurah al-Tirmîdzî, al-Jâmi' al-Shahîh wa Huwa Sunan al-Tirmîdzî, Juz II, Tahqiq Ahmad Muhammad Syâkir, hadits ke 207 (Mesir: Mushthafâ al-Bâbî al-Halabî wa Aulâduh, 1978), 176. Lihat juga Abû Îsâ Muhammad bin Îsâ bin Saurah al-Tirmîdzî, al-Jâmi' al-Kabîr, Jilid 1, hadits ke 345 (Beirut: Dâr alGharb al-Islâmî, 1996), 374.
} 
diantara kami melakukan shalat di hadapannya. Maka ketika pagi hari kami menceritakan peristiwa itu kepada Nabi saw, maka turun ayat 'Maka kemana kamu menghadap, maka disitulah wajah Allah.'

Berdasarkan dalil-dalil di atas dapat disimpulkan bahwa menghadap kiblat hukumnya wajib saat shalat. Kiblat sendiri adalah Ka'bah. Sehingga wajib bagi orang-orang yang tinggal di sekitar Masjid al-Haram untuk menghadap tepat ke arah Ka'bah. Sementara orang-orang yang tinggal jauh dari Masjid al-Haram, mereka harus menghadap ke arah Mekkah saja (yang didalamnya terdapat Ka'bah). Adapun orang yang bingung atau tidak dapat mengetahui arah kiblat yang benar, maka cukup bagi mereka menghadap ke arah mana saja yang mereka yakini sebagai arah kiblat.

\section{Kajian-kajian Akurasi Arah Kiblat}

Ada dua buah penelitian terdahulu yang berhubungan dengan arah kiblat masjid di Kabupaten Pamekasan dengan beberapa metode pengukuran. Namun substansinya berbeda dengan penelitian ini. Misalnya Penetuan Waktu Shalat dan Kalibrasi Arah Kiblat - Menakar Problematika Akurasi Masjid-Masjid di Pamekasan melalui Pengabdian Masyarakat Berbasis Syariah/Hukum. ${ }^{34}$ Adalah penelitian yang dilakukan oleh tim pengabdian kepada masyarakat (PKM) berbasis syariah yang melibatkan beberapa dosen STAIN Pamekasan. Penelitian ini berbasis pengabdian kepada masyarakat yang memfokuskan pada pengukuran arah kiblat dan penentuan awal waktu shalat. Penelitian tersebut sedikit ada kesamaan dengan penelitian ini. Hanya saja tempat, metode yang digunakan dan jumlah masjidnya yang berbeda.

Akurasi Arah Kiblat Masjid-Masjid di Kabupaten Pamekasan (Analisis Menggunakan Spherical Trigonometry). ${ }^{35}$ Penelitian ini menggunakan sampel 55 buah masjid se-kabupaten Pamekasan. Hanya saja tidak dicantumkan secara keseluruhan nama-nama masjid

34 Achmad Mulyadi, dkk, Penentuan Waktu Shalat dan Kalibrasi Arah Kiblat - Menakar Problematika Akurasi Masjid-Masjid di Pamekasan melalui Pengabdian Masyarakat Berbasis Syariah/Hukum - (Sumenep: Penerbit Yayasan Al-Fatah, 2016).

35 Achmad Mulyadi, Akurasi Arah Kiblat Masjid-Masjid di Kabupaten Pamekasan (Analisis Menggunakan Spherical Trigonometry), (artikel dalam Jurnal Nuansa, Volume 10, Nomor 1, Januari-Juni 2013). Selanjutnya disebut Mulyadi. 
yang telah dilakukan pengukuran ulang arah kiblatnya. Sehingga menurut pandangan penulis, hasil penelitian di atas tidak fokus kepada wilayah tertentu seperti wilayah kecamatan. Metode yang digunakanpun tidak sama dengan metode penelitian ini. Sepanjang yang telah ditelusuri, sampai saat ini belum ada penelitian terhadap akurasi arah kiblat baik masjid maupun mushalla dengan menggunakan Mizwala.

\section{Peralatan dan Cara Mengukur Kiblat}

Dalam ilmu hisab yang berhubungan dengan pengukuran/penentuan arah kiblat, terdapat beberapa cara/metode yang digunakan oleh para ahli. Mulai dari alat yang sederhana sampai digital hingga berbasis satelit. Bahkan gabungan dari ketiganya untuk menghasilkan pengukuran yang akurat.

Hasil wawancara tentang peralatan yang digunakan ketika mengukur/menentukan arah kiblat masjid di wilayah Kecamatan Pademawu terdiri dari beberapa metode yang berbeda. Dari 21 buah masjid yang menjadi sampel penelitian, sebanyak sepuluh (10) masjid $(47,61 \%)$ menggunakan kompas sebagai alat pengukur/penentu arah kiblat. Terdapat tiga masjid (14,28\%) mengikuti petunjuk tokoh masyarakat setempat. Sementara tiga masjid yang lain $(14,28 \%)$ takmirnya tidak mengetahui tentang alat yang digunakan ketika menentukan arah kiblat masjid karena usia masjidnya yang sudah lama (tua), dan para founding father-nya (takmir/pengurus pertama) sudah wafat. Ada satu masjid (4,76\%) yang menggunakan rubu' mujayyab, satu masjid (4.76\%) menggunakan bhencèt ${ }^{36}$, satu masjid $(4.76 \%)$ mengikuti pondasi masjid lama dan satu masjid $(4,76 \%)$ hanya menyerongkan sebesar 5 derajat dari arah barat ke utara.

Situasi dan kondisi seperti di atas merupakan problem yang banyak dihadapi oleh masyarakat Kabupaten Pamekasan pada umumnya. Hal ini terjadi karena orang yang ahli dalam mengukur arah kiblat pada saat itu terbilang langka. Kurangnya pemahaman masyarakat terhadap hakikat "menghadap" kiblat ketika

36 Bhencèt adalah alat sederhana yang terbuat dari semen atau semacamnya yang diberi tongkat di tengah-tengahnya dan diletakkan ditempat terbuka (biasanya di depan masjid) untuk mendapatkan sinar matahari. Alat ini berguna untuk mengetahui waktu matahari hakiki, tanggal syamsiyah serta pranotomongso. Lihat Muhyiddin Khazin, Kamus..., 12. 
melaksanakan shalat, minimnya masyarakat yang mau belajar tentang tata cara mengukur arah kiblat, tidak adanya pembinaan dari pemerintah daerah dan tokoh agama, menjadi kunci banyaknya masjid yang arah kiblatnya tidak akurat. ${ }^{37}$

Mengenai proses pengukuran/penentuan arah kiblat dengan menggunakan metode di masing-masing masjid, sebanyak 11 takmir masjid (52,38\%) mengetahui proses pengukurannya. Karena responden yang bersangkutan turut serta atau terlibat dalam pengukuran kiblat masjidnya. Dan 10 takmir masjid (47,62\%) mengaku tidak mengetahuinya dengan alasan, bahwa usia masjid tergolong masjid yang sudah lama di bangun, dan para pelaku sejarahnya sudah wafat. Ada pula yang mengatakan, bahwa ketika pengukuran/penentuan arah kiblat masjid tidak mengikuti proses pengukurannya. Selain itu, dalam proses pengukuran/penetapan arah kiblat, takmir atau panitia setempat mengundang beberapa elemen masyarakat seperti tokoh masyarakat dan aparat desa.

Mengukur arah kiblat dengan menggunakan kompas dengan cara diletakkan di bawah, harus menunggu sampai jarum kompas stabil. Kemudian tandai arah utara, selatan, barat dan timur dengan menggunakan benang. Setelah itu mengambil arah 24 derajat dari arah barat ke utara. Bentangkan benang pada arah 24 derajat tersebut. Itulah arah kiblatnya.

Dari hasil pengukuran ulang banyak arah kiblat masjid yang kurang akurat, dapat disimpulkan bahwa telah terjadi kesalahan dalam menggunakan media kompas tersebut. Kompas rentan dengan benda-benda bermagnet seperti logam, jam tangan, besi dan lainnya. Bisa saja di sekitar kompas terdapat besi atau logam peralatan pertukangan. Hal tersebut dapat menyebabkan masalah akurasi pengukuran arah kiblat dengan menggunakan kompas. Tidak direkomendasikan penggunakan kompas sebagai alat pengukur kiblat kecuali untuk latihan dan atau dalam situasi dan kondisi yang mengharuskan memakai kompas. Itupun harus dikombinasikan dengan alat lainnya seperti dengan Teodolite.

\section{Akurasi Arah Kiblat Masjid Berdasarkan Mizwala}

37 Mulyadi, Akurasi Arah Kiblat. 
Untuk mencapai hasil pengukuran yang maksimal, dalam penelitian ini, selain Mizwala, 38 terdapat pula alat pendukung yang disertakan, seperti GPS Garmin Etrex 10, kompas, waterpass, benang dan Smart Phone Samsung Galaxy SII Plus-GT19105P guna menjalankan aplikasi program Excel yang merupakan panduan rumus yang dibuat khusus untuk Mizwala.

Dari hasil observasi tersebut ditemukan hanya 6 buah masjid $(28,57 \%)$ yang arah kiblatnya akurat. Ada 9 buah masjid $(42,85 \%)$ yang arah kiblat kurang ke utara dari titik barat dengan nilai yang bervariasi antara 2 derajat sampai dengan 14 derajat 51 menit busur. Dan terdapat 6 buah masjid yang lain (28,57\%) yang arah kiblatnya kurang ke selatan dengan variasi 9 menit busur sampai 10 derajat 9 menit busur, sebagaimana tabel di bawah ini:

Tabel Rekapitulasi Hasil Observasi

\begin{tabular}{|c|c|c|c|c|c|}
\hline NO. & $\begin{array}{l}\text { NAMA } \\
\text { MASJID }\end{array}$ & $\begin{array}{l}\text { LINTANG/ } \\
\text { BUJUR *) }\end{array}$ & $\begin{array}{c}\text { AZIMUT } \\
\left.\text { KIBLAT }^{* *}\right)\end{array}$ & \begin{tabular}{|c|} 
ARAH \\
BANGUN \\
AN
\end{tabular} & $\underset{* * *)}{\text { SELISIH }}$ \\
\hline 1. & At-Taqwa & $\begin{array}{l}07^{\circ} 10^{\prime} 40.76^{\prime \prime} \mathrm{S} \\
113^{\circ} 30^{\prime} 43.77^{\prime \prime} \mathrm{T}\end{array}$ & $293^{\circ} 50^{\prime}$ & $293^{\circ} 50^{\prime}$ & - \\
\hline 2. & $\begin{array}{l}\text { Darul } \\
\text { Mukhlishin }\end{array}$ & $\begin{array}{l}07^{\circ} 11^{\prime} 10.99^{\prime \prime} \mathrm{S} \\
113^{\circ} 30^{\prime} 46.73^{\prime \prime} \mathrm{T}\end{array}$ & $293^{\circ} 51^{\prime}$ & $283^{\circ}$ & (-) $10^{\circ} 51^{\prime}$ \\
\hline 3. & Nurul Ihsan & $\begin{array}{l}07^{\circ} 09^{\prime} 12.22^{\prime \prime} \mathrm{S} \\
113^{\circ} 30^{\prime} 12.51^{\prime \prime} \mathrm{T}\end{array}$ & $293^{\circ} 50^{\prime}$ & $288^{\circ}$ & (-) $5^{\circ} 50^{\prime}$ \\
\hline 4. & $\begin{array}{l}\text { Baitul } \\
\text { Muqarrabin }\end{array}$ & $\begin{array}{l}07^{\circ} 09^{\prime} 00.32^{\prime \prime} \mathrm{S} \\
113^{\circ} 30^{\prime} 51.46^{\prime \prime} \mathrm{T}\end{array}$ & $293^{\circ} 50^{\prime}$ & $290^{\circ} 45^{\prime}$ & $(-) 2^{\circ} 5^{\prime}$ \\
\hline 5. & $\begin{array}{l}\text { Miftahus } \\
\text { Sa'adah }\end{array}$ & $\begin{array}{l}07^{\circ} 13^{\prime} 27.56^{\prime \prime} \mathrm{S} \\
113^{\circ} 31^{\prime} 08.83^{\prime \prime} \mathrm{T}\end{array}$ & $293^{\circ} 51^{\prime}$ & $293^{\circ} 51^{\prime}$ & - \\
\hline 6. & Nurul Yaqin & $\begin{array}{l}07^{\circ} 13^{\prime} 09.85^{\prime \prime} \mathrm{S} \\
113^{\circ} 31^{\prime} 51.94^{\prime \prime} \mathrm{S}\end{array}$ & $293^{\circ} 51^{\prime}$ & $293^{\circ} 51^{\prime}$ & - \\
\hline 7. & Istikmal & $\begin{array}{l}07^{\circ} 12^{\prime} 27.18^{\prime \prime} \mathrm{S} \\
113^{\circ} 32^{\prime} 08.81^{\prime \prime} \mathrm{T}\end{array}$ & $293^{\circ} 50^{\prime}$ & $290^{\circ} 50^{\prime}$ & (-) $03^{\circ}$ \\
\hline 8. & Al-Jaziel & $\begin{array}{l}07^{\circ} 12^{\prime} 26.20^{\prime \prime} \mathrm{S} \\
113^{\circ} 29^{\prime} 53.81^{\prime \prime} \mathrm{T}\end{array}$ & $293^{\circ} 51^{\prime}$ & $295^{\circ} 51^{\prime}$ & $(+) 2^{\circ}$ \\
\hline 9. & Al-Bushro & $\begin{array}{l}07^{\circ} 13^{\prime} 17.26^{\prime \prime} \mathrm{S} \\
113^{\circ} 28^{\prime} 39.80^{\prime \prime} \mathrm{T} \\
\end{array}$ & $293^{\circ} 51^{\prime}$ & $293^{\circ} 51^{\prime}$ & - \\
\hline 10. & As-Syakirin & $\begin{array}{l}07^{\circ} 13^{\prime} 30.11^{\prime \prime} \mathrm{S} \\
113^{\circ} 29^{\prime} 58.91^{\prime \prime} \mathrm{T}\end{array}$ & $293^{\circ} 51^{\prime}$ & $295^{\circ} 51^{\prime}$ & $(+) 2^{\circ}$ \\
\hline
\end{tabular}

${ }^{38}$ Mizwala yang penulis gunakan adalah produksi tahun 2010 dengan bahan kayu. 


\begin{tabular}{|c|l|l|r|r|c|}
\hline 11. & Asy-Syuhada & $\begin{array}{l}07^{\circ} 11^{\prime} 42.08^{\prime \prime} \mathrm{S} \\
113^{\circ} 29^{\prime} 12.05^{\prime \prime} \mathrm{T}\end{array}$ & $293^{\circ} 51^{\prime}$ & $293^{\circ} 51^{\prime}$ & - \\
\hline 12. & Al-Amin & $\begin{array}{l}07^{\circ} 11^{\prime} 34.15^{\prime \prime} \mathrm{S} \\
113^{\circ} 30^{\prime} 10.59^{\prime \prime} \mathrm{T}\end{array}$ & $293^{\circ} 51^{\prime}$ & $294^{\circ}$ & $(+) 0^{\circ} 09^{\prime}$ \\
\hline 13. & Al-Falah & $\begin{array}{l}07^{\circ} 12^{\prime} 05.03^{\prime \prime} \mathrm{S} \\
113^{\circ} 29^{\prime} 39.00^{\prime \prime} \mathrm{T}\end{array}$ & $293^{\circ} 51^{\prime}$ & $318^{\circ}$ & $(-) 24^{\circ} 09^{\prime}$ \\
\hline 14. & Nurul Falah & $\begin{array}{l}07^{\circ} 11^{\prime} 51.13^{\prime \prime} \mathrm{S} \\
113^{\circ} 29^{\prime} 22.93^{\prime \prime} \mathrm{T}\end{array}$ & $293^{\circ} 51^{\prime}$ & $304^{\circ}$ & $(+) 10^{\circ} 09^{\prime}$ \\
\hline 15. & Al-Abrori & $\begin{array}{l}07^{\circ} 09^{\prime} 14.06^{\prime \prime} \mathrm{S} \\
113^{\circ} 29^{\prime} 59.50^{\prime \prime} \mathrm{T}\end{array}$ & $293^{\circ} 50^{\prime}$ & $293^{\circ} 50^{\prime}$ & - \\
\hline 16. & As-Shinhaji & $\begin{array}{l}07^{\circ} 08^{\prime} 06.83^{\prime \prime} \mathrm{S} \\
113^{\circ} 30^{\prime} 38.85^{\prime \prime} \mathrm{T}\end{array}$ & $293^{\circ} 50^{\prime}$ & $299^{\circ}$ & $(+) 5^{\circ} 10^{\prime}$ \\
\hline 17. & Rahmatullah & $\begin{array}{l}07^{\circ} 10^{\prime} 38.73^{\prime \prime} \mathrm{S} \\
113^{\circ} 29^{\prime} 47.21^{\prime \prime} \mathrm{T}\end{array}$ & $293^{\circ} 51^{\prime}$ & $282^{\circ}$ & $(-) 11^{\circ} 51^{\prime}$ \\
\hline 18. & Nurul Huda & $\begin{array}{l}07^{\circ} 13^{\prime} 56.94^{\prime \prime} \mathrm{S} \\
113^{\circ} 31^{\prime} 47.50^{\prime \prime} \mathrm{T}\end{array}$ & $293^{\circ} 51^{\prime}$ & $279^{\circ} 00^{\prime}$ & $(-) 14^{\circ} 51^{\prime}$ \\
\hline 19. & Nurul Huda & $\begin{array}{l}07^{\circ} 09^{\prime} 37.04^{\prime \prime} \mathrm{S} \\
113^{\circ} 30^{\prime} 56.36^{\prime \prime} \mathrm{T}\end{array}$ & $293^{\circ} 50^{\prime}$ & $279^{\circ} 45^{\prime}$ & $(-) 14^{\circ} 5^{\prime}$ \\
\hline 20. & Asy-Syuhada & $\begin{array}{l}07^{\circ} 10^{\prime} 54.53^{\prime \prime} \mathrm{S} \\
113^{\circ} 30^{\prime} 08.77^{\prime \prime} \mathrm{T}\end{array}$ & $293^{\circ} 50^{\prime}$ & $285^{\circ}$ & $(-) 8^{\circ} 50^{\prime}$ \\
\hline 21. & Haqqul Yaqin & $\begin{array}{l}07^{\circ} 11^{\prime} 07.15^{\prime \prime} \mathrm{S} \\
113^{\circ} 31^{\prime} 33.63^{\prime \prime} \mathrm{T}\end{array}$ & $293^{\circ} 50^{\prime}$ & $292^{\circ} 10^{\prime}$ & $(-) 1^{\circ} 40^{\prime}$ \\
\hline
\end{tabular}

Catatan:

*) : Karena yang menjadi obyek observasi adalah wilayah Madura, maka lintangnya adalah lintang selatan (dihitung ke selatan dari katulistiwa) dan bujurnya bujur timur (dihitung ke timur dari bujur Greenwich Inggris).

**) : Azimut Kiblat adalah arah kiblat yang dihasilkan dari lintang dan bujur masjid setempat dengan menggunakan perhitungan software Mizwala.

***) : Adalah selisih nilai busur antara azimut kiblat dengan arah bangunan masjid. Lambang (-) menunjukkan bahwa nilai selisih tersebut kurang ke arah utara, dan lambang $(+)$ menunjukkan nilai selisih tersebut lebih ke utara (kurang ke arah selatan) bangunan masjidnya.

Terjadinya deviasi (penyimpangan) arah kiblat 15 buah masjid $(71,43 \%)$ diatas, disebabkan oleh beberapa faktor, seperti: (1) arah kiblat masjid tersebut tidak dihitung dan tidak diukur, tetapi hanya berdasarkan petunjuk dari tokoh masyarakat setempat atau hanya memperkirakan dengan menyerongkan 5 derajat dari arah barat ke 
utara; (2) tidak dihitung tetapi langsung diukur. Yang penting sesuai dengan kompas, langsung diberi tanda dengan bentangan benang tanpa dihitung terlebih dahulu dan tanpa memperhatikan deklinasi kompas dan hal-hal lain yang mempengaruhi kinerja kompas; dan (3) bangunan masjid mengikuti lokasi kavling tanah bahkan mengikuti arah jalan raya.

Sementara 6 masjid (28,57\%) yang arah kiblatnya akurat dapat disimpulkan bahwa para juru ukur saat itu sudah mengetahui dan memahami perihal ilmu hitung dan ilmu ukur dalam astronomi/ilmu falak. Dari 6 masjid tersebut, 4 buah masjid arah kiblatnya diukur dengan menggunakan kompas dan sisanya 2 buah masjid masingmasing menggunakan rubu' mujayyab dan bhencèt.

\begin{tabular}{|c|l|c|c|}
\hline No. & \multicolumn{1}{|c|}{ Nama Masjid } & $\begin{array}{c}\text { Tahun } \\
\text { Pembangunan }\end{array}$ & $\begin{array}{c}\text { Alat ukur kiblat yang } \\
\text { digunakan }\end{array}$ \\
\hline 1. & At-Taqwa & $1957 \mathrm{M}$ & Rubu'Mujayyab \\
\hline 2. & Miftahus Sa'adah & $1991 \mathrm{M}$ & Kompas \\
\hline 3. & Nurul Yaqin & $1992 \mathrm{M}$ & Kompas \\
\hline 4. & Al-Busro & $1996 \mathrm{M}$ & Kompas \\
\hline 5. & Asy-Syuhada & $1965 \mathrm{M}$ & Bhencèt \\
\hline 6. & Al-Abrori & $2012 \mathrm{M}$ & Kompas \\
\hline
\end{tabular}

Dengan demikian, bahwa untuk mengukur arah kiblat yang akurat, dibutuhkan kemampuan yang memadai baik kemampuan dalam menguasai ilmu perhitungan trigonometri (segitiga bola) maupun kemampuan dalam menguasai alat ukur dari berbagai jenis, mulai alat ukur klasik seperti kompas dan rubu', maupun alat ukur kontemporer seperti Mizwala, Istiwa`ain dan Teodolite.

\section{Kesimpulan}

Berdasarkan hasil temuan dan paparan data, dapat ditarik kesimpulan: pertama; alat yang digunakan dalam mengukur arah kiblat masjid di wilayah Kecamatan Pademawu Kabupaten Pamekasan, terdiri dari; kompas, kompas sajadah, rubu' mujayyab, dan bhencèt. Dan yang paling banyak digunakan adalah kompas dan kompas sajadah. Kedua; dalam melakukan proses pengukuran arah kiblat masjid, takmir masjid melibatkan beberapa elemen masyarakat, mulai dari pengelola masjid sendiri, tokoh masyarakat, aparat desa 
setempat hingga masyarakat sekitar. Cara melakukan pengukuran kiblat sangat sederhana, cukup meletakkan kompas untuk mencari arah barat, kemudian dilakukan serong ke utara kira-kira 24 derajat yang ditandai dengan benang. Ketiga; hasil pengukuran ulang dengan menggunakan metode Mizwala Qibla Finder (MQF) hanya ada enam (6) masjid $(28,57 \%)$ yang arah kiblatnya akurat. Lainnya mengalami penyimpangan (deviasi) yang bervariasi. []

\section{Daftar Pustaka}

al-'Asqalânî, Ahmad bin 'Alî bin Hajar. Fath al-Bârî bi Syarh Shahîh alImâm Abî̀ 'Abdullâh Muhammad bin Ismâil al-Bukhârî. Tahqîq 'Abd al-Qâdir Syaibah al-Hamd. Juz IV. Riyâdl: al-Amir Sulthân bin 'Abd al-'Azîz Âlu Sa' ûd, 2001

Azhari, Susiknan. Ensiklopedi Hisab Rukyat. Yogyakarta: Pustaka Pelajar, 2012

al-Bayhaqî, Abû Bakar Ahmad bin al-Husayn bin 'Alî. al-Sunan alKubrâ. Tahqîq 'Abd al-Qâdir 'Athâ. Juz II. Beirut; Dâr al-Kutub al-'Ilmiyyah, 2003

Bisri, Abid. Kamus al-Bisri. Surabaya: Pustaka Progressif, 1999;

Dahlan, Abdul Aziz et. Al. Ensiklopedi Hukum Islam. Cet. 1. Jakarta: Ichtiar Baru van Hoeve, 1996

al-Dzahabî. Mukhtârât min Siyari A'lâm al-Nubalâ' wa Târîkh al-Islâmî. Yordania: Dâr al-Nafâis, 2015

Departemen Agama. Alqur'an dan terjemahnya. Bandung: Jumanatul 'Ali-ART, 2005

Fathullâh, Ahmad Ghazâlî Muhammad. Irsyâd al-Murîd. Cet. III. Sampang: Lajnah Falakiyah al-Mubarok Lanbulan, 2005

Hosen. Zenit; Panduan Perhitungan Azimut Syathr Kiblat dan Awal Waktu Shalat. Pamekasan: Duta Media, 2016

Kadir, A. Figh Qibllat. Yogyakarta: Pustaka Pesantren, 2012

Khazin, Muhyiddin. Kamus Ilmu Falak. Jogjakarta: Buana Pustaka, 2005

Mandhûr, Ibn. Lisân al-'Arab. Jilid 4. Kairo: Dâr al-Ma'arif, t.t.

Ma'shûm bin Alî, Syaikh Muhammad. al-Durus al-Falakiyyah. Jilid 1. Jombang: TP, 1992

Mulyadi, Achmad. Dkk. Penetuan Waktu Shalat dan Kalibrasi Arah Kiblat - Menakar Problematika Akurasi Masjid-Masjid di Pamekasan 
melalui Pengabdian Masyarakat Berbasis Syariah/Hukum. Sumenep: Penerbit Yayasan Al-Fatah, 2016

Mulyadi, Achmad. Akurasi Arah Kiblat Masjid-Masjid di Kabupaten Pamekasan (Analisis Menggunakan Spherical Trigonometry). Jurnal Nuansa, Volume 10, Nomor 1, Januari-Juni 2013

el-Moeid, Ibnu Zahid Abdo. Menentukan Arah Qiblat Dengan Benar. Makalah disampaikan dalam diklat ilmu falak Tsamrah al-Fikar $\mathcal{E}$ Arah Qiblat, Ponpes "Al-Mubarok" Lanbulan Baturasang Tambelangan, Sampang: 1-2 Mei 2011

Munawwir, Ahmad Warson. Kamus Al-Munawwir; Arab-Indonesia. Cet. I. Yogyakarta: Pustaka Progresif, 1984.

Setyanto, Hendro. Mizwala Qibla Finder. Makalah disampaikan dalam pelatihan hisab dan rukyat, Lajnah Falakiyah Nahdhatul Ulama (LFNU). Pamekasan, 12 Mei 2010

al-Syirâzî, Majd al-Dîn Muhammad binYa'qûb al-Fairuz Abadî. alQâmus al-Muhîth. Kairo: al-Hay’ah al-Mishriyyah, t.t.

al-Tirmidzî, Abû Îsâ Muhammad bin Îsâ bin Saurah. al-Jâmi' al-Shahîh wa Huwa Sunan al-Tirmîdzî. Juz II. Tahqiq Ahmad Muhammad Syâkir. Mesir: Mushthafâ al-Bâbî al-Halabî wa Aulâduh, 1978 . al-Jâmi' al-Kabîr. Jilid I. Beirut: Dâr al-Gharb al-Islâmî, 1996; 